\title{
DETERMINAN AUDITOR SWITCHING PADA PERUSAHAAN FINANCE YANG TERDAFTAR DI BEI
}

\section{Muhammad Fauzi ${ }^{*}$, Amir Hasan ${ }^{2}$, Vera Oktari ${ }^{3}$}

${ }^{1,2,3}$ Program Studi Akuntansi, Fakultas Ekonomi dan Bisnis , Universitas Riau, Pekanbaru, *E-mail: mfauji79@gmail.com

\begin{tabular}{l} 
Keywords \\
\hline Auditor switching \\
Company growth Audit \\
delay \\
Financial distress \\
Audit opinion
\end{tabular}

\begin{tabular}{l} 
Article information \\
\hline Received: \\
2020-01-23 \\
Accepted: \\
2020-02-04 \\
Available Online: \\
2020-02-25
\end{tabular}

\begin{abstract}
This study aims to examine the factors that determine the change of auditors in finance companies. Companiy growth, audit delay, firm size, managerial ownership, change in management, financial distress, KAP size, and audit opinion used to determine auditor switching. The sample used in this study consisted of 11 samples of finance companies listed on the Indonesian Stock Exchange during 2013-2017. The sample in this study used purposive sampling method. Data analysis method uses logistic regression analysis using SPSS version 23.0. The result shows company's growth, audit delay, company size, management financial distress have effect on switching Auditors while audit opinion, KAP size and managerial ownership has no effect on auditor switching.
\end{abstract}

\section{PENDAHULUAN}

Auditor switching merupakan perpindahan auditor atau KAP yang dilakukan oleh perusahaan klien. Fenomena auditor switching masih menarik untuk dikaji. Kajian mengenai auditor switching ini berawal dari terbongkarnya kasus Enron yang mengakibatkan lahirnya Sarbanes Oxley Act. Menindak lanjuti kasus ini pemerintah Indonesia mengatur kewajiban untuk melakukan pergantian auditor dengan mengeluarkan peraturan Mentri Keuangan Nomor 17/PMK.01/2008 yang merupakan penyempurnaan dari peraturan sebelumnya yakni Keputusan Menteri Keuangan No.359/KMK.06/2003 dan No.423/KMK.06/2002. Perubahan peraturan ini menyatakan bahwa pemberian jasa audit umum atas laporan keuangan dari suatu entitas dapat dilakukan paling lama 6 (enam) tahun buku berturut-turut oleh KAP yang sama dan 3 (tiga) tahun berturut-turut oleh auditor yang sama kepada satu klien yang sama (pasal 3 ayat 1$)$.

Menurut Chadegani et al. (2011) ada dua faktor yang menyebabkan terjadinya auditor switching yaiu diantaranya berasal dari auditor dan faktor yang berasal dari klien. Faktor yang 
berasal dari auditor seperti opini audit, fee audit, dan kualitas audit, sedangkan faktor yang berasal dari klien seperti meningkat atau menurunnya pertumbuhan perusahaan, pergantian manajemen, ukuran perusahaan, dan financial distress. Faktor tersebut dapat menyebabkan auditor switching dan juga dapat mengganggu independesi auditor.

Kemudian disamping itu juga dapat dilihat dari hubungan kerja yang panjang antara auditor dan klien yang akan menimbulkan keakraban yang lebih sehingga dapat mengancam independensi auditor tersebut. Oleh sebab itulah muncul gagasan adanya rotasi audit. Pemerintah Indonesia telah mengatur kewajiban rotasi auditor dengan dikeluarkannya Peraturan Menteri Keuangan Republik Indonesia Nomor 17/PMK.01/2008 tentang "Jasa Akuntan Publik”.

Kemudian dilakukan pembaharuan Peraturan Menteri Keuangan menjadi Peraturan Pemerintah Republik Indonesia Nomor 20 Tahun 2015 tentang praktik Akuntan Publik, tetapi yang menjadi masalah adalah jika auditor switching bersifat voluntary (di luar peraturan) bukan mandatory (berdasarakan aturan). Menurut Meidiyustiani (2018), ada beberapa faktor yang menyebabkan auditor switching secara voluntary dan tidak menaati peraturan yang berlaku. Faktor tersebut seperti akuntan yang memiliki sertifikat akuntan publik, ukuran Perusahaan, kepemilikan manajerial, dan audit delay. Sedangkan penelitian yang dilakukan oleh Pasaribu (2017) menggunakan faktor-faktor seperti audit delay, financial distress, biaya audit, dan opini audit. Dalam penelitian ini dibahas mengenai pertumbuhan perusahaan, audit delay, ukuran perusahaan, kepemilikan manajerial, pergantian manajemen, financial distress, ukuran KAP, dan opini audit yang memungkinkan perusahaan akan melakukan auditor switching secara voluntary.

Pertumbuhan perusahaan merupakan ukuran seberapa baik perusahaan mempertahankan kondisi finansialnya, baik dalam industrinya maupun dalam kegiatan ekonomi secara keseluruhan. Penelitian yang dilakukan oleh Wandari (2017) menyatakan bahwa pertumbuhan perusahaan memiliki pengaruh terhadap auditor switching, sedangkan penelitian yang dilakukan oleh Sinarto (2018) dan penelitian Pamungkas (2018) yang menyatakan bahwa pertumbuhan perusahaan tidak memliki pengaruh terhadap auditor switching.

Audit delay merupakan suatu penyelesaian tugas audit yang memiliki rentang waktu yang terlalu lama dan mengakibatkan keterlambatan perusahaan untuk mempublikasikan laporan keuangan ke pasar modal atau Otoritas Jasa Keuangan. Peneilitan yang dilakukan oleh Soraya (2017) dan Robbitasari (2013) menyatakan bahwa bahwa suatu penyelesaian tugas audit yang memiliki rentang waktu yang terlalu lama akan mengakibatkan 
keterlambatan mempublikasikan laporan keuangan ke pasar modal sehingga berpengaruh pada auditor switching. Namun Meidiyustiani (2018) menyatakan audit delay tidak berpengaruh terhadap auditor switching.

Ukuran perusahaan merupakan besarnya ukuran sebuah perusahaan yang diukur berdasarkan total aset. Penelitian yang dilakukan oleh Netti (2014) mendapatkan hasil bahwa ukuran perusahaan berpengaruh negatif terhadap auditor switching. Namun, penelitian yang dilakukan oleh Aminah (2017) menyatakan bahwa ukuran perusahaan tidak memiliki pengaruh terhadap auditor switching.

Menurut Rianti (2014) kepemilikan manajerial adalah pemegang saham yang juga berarti sebagai pemilik di dalam perusahaan dari manajemen yang aktif dalam memberikan keputusan di perusahaan yang bersangkutan. Hasil penelitian terdahulu oleh Meidiyustiani (2018) mendapatkan hasil bahwa kepemilikan manajerial berpengaruh terhadap auditor switching. Penelitian oleh Maharani dan Purnomosidhi (2012) menemukan bahwa tingkat kepemilikan manajerial berpengaruh positif dan signifikan terhadap auditor switching. Namun penelitian oleh Astyorini (2015) menyatakan bahwa kepemilikan manajerial tidak berpengaruh terhadap auditor switching.

Pergantian manajemen merupakan adanya pergantian direktur utama atau CEO (Chief Executive Oviccer) yang dilakukan oleh perusahaan dalam keputusan Rapat Pemegang Saham. Penelitian yang dilakukan Luthfiyati (2016) menyatakan bahwa pergantian manajemen berpengaruh negatif terhadap auditor switching. Namun berbeda dengan penelitian yang dilakukan oleh Kencana (2018) yang menyatakan bahwa pergantian manjemen tidak memiliki pengaruh terhadap auditor switching.

Financial distress merupakan suatu kondisi perusahaan yang sedang mengalami kesulitan keuangan dan terancam bangkrut. Wea dan Murdiawati (2015), Varadita (2012) yang menyatakan bahwa financial distress berpengaruh signifikan terhadap auditor switching. Sedangkan pada penelitian yang dilakukan oleh Susanto (2018) menyatakan bahwa financial distress tidak berpengaruh terhadap auditor switching.

Ukuran KAP merupakan ukuran yang digunakan untuk menentukan besar dan kecilnya suatu KAP (Fakhri, 2018). Penelitian yang dilakukan oleh Efendi (2015) dan penelitian yang dilakukan oleh Aprianti (2016) menyatakan bahwa ukukan KAP memiliki pengaruh terhadap auditor switching. Penelitian yang sama dilakukan oleh Manto dan Manda (2018) menyatakan ukuran KAP memiliki pengaruh signifikan negatif terhadap auditor switching. Namun Oktaviana (2017) menyatakan bahwa ukuran KAP tidak berpengaruh terhadap auditor switching. 
Opini audit merupakan pernyataan pendapat yang diberikan oleh auditor dalam menilai kewajaran laporan keuangan yang diauditnya. Penelitian yang dilakukan Faradila (2016) dan juga penelitian yang dilakukan oleh Fakhri (2018) dimana hasil penelitian yang mereka dapatkan bahwa opini audit memiliki pengaruh terhadap auditor switching. Berbeda dengan penelitian yang dilakukan oleh Efendi (2015) dan Oktaviana (2017) menyatakan bahwa opini audit tidak memiliki pengaruh terhadap auditor switching. Objek pada penelitian ini adalah perusahaan Finansial yang terdaftar di Bursa Efek Indonesia periode 2010-2017.

Penelitian ini berbeda dengan penelitian Pasaribu (2017) yang menggunakan audit delay, financial distress, biaya audit, dan opini audit dalam mempengaruhi auditor switching. Penelitian mengenai auditor switching masih menarik untuk dikaji dengan mengembangkan penelitian sebelumnya. Penelitian ini memperluas kajian dengan menguji pertumbuhan perusahaan, audit delay, ukuran perusahaan, kepemilikan manajerial, perubahan manajemen, kesulitan keuangan, ukuran KAP, dan opini audit sebagai faktor yang menenentukan pergantian auditor (auditor switching). Sebagaimana telah dijelaskan sebelumnya dalam penelitian Maharani dan Purnomosidhi (2012); Faradila (2016); Efendi (2015) bahwa kepemilikan manajerial, ukuran KAP serta opini audit dapat mempengaruhi auditor switching.

\section{PENGEMBANGAN HIPOTESIS}

\section{Pertumbuhan Perusahaan Terhadap Auditor Switching}

Menurut Aprianti (2016) menyatakan bahwa dengan pertumbuhan perusahaan, maka akan semakin kompleks kegiatan operasi perusahaan dan cenderung membutuhkan auditor yang lebih berkualitas. Hasil penelitian Faradila (2016) menunjukkan bahwa semakin tinggi pertumbuhan perusahaan klien maka tindakan auditor switching juga meningkat, hal ini dilakukan untuk mendapatkan auditor yang dapat memenuhi tuntutan pertumbuhan perusahaan, meningkatkan reputasi perusahaan, mendapatkan kepercayaan pemegang saham, dan menarik para calon investor untuk berinvestasi.

\section{$\mathrm{H}_{1}$ : Pertumbuhan Perusahaan berpengaruh terhadap Auditor Switching.}

\section{Audit Delay Terhadap Auditor Switching}

Panjang-pendeknya audit delay menjadi penentu ketepatwaktuan perusahaan dalam mempublikasikan laporan keuangan ke pasar modal atau Otoritas Jasa Keuangan. Untuk mengantisipasi hal buruk atau terjadinya audit delay tersebut, perusahaan melakukan auditor switching untuk periode berikutnya, agar laporan tahun selanjutnya tidak mengalami audit delay. Hasil penelitian Soraya (2017) dan Robbitasari (2013) menunjukkan audit delay 
berpengaruh terhadap auditor switching. Berdasarkan uraian diatas maka dihipotesiskan:

\section{$\mathrm{H}_{2}$ : Audit Delay berpengaruh terhadap Auditor Switching.}

\section{Ukuran Perusahaan Terhadap Auditor Switching}

Nazrie et al. (2012) berpendapat bahwa ketika perusahaan telah meningkatkan ukuran akan menyebabkan meningkatnya kesulitan bagi pemilik dalam memantau tindakan manajer sebagai prinsipal dan agen menjadi lebih jauh, sehingga perusahaan mungkin membutuhkan auditor yang baru (kualitas yang lebih tinggi) untuk menyediakan pemantauan yang lebih baik. Hasil penelitian Netti (2014) menunjukkan ukuran perusahaan berpengaruh terhadap auditor switching. Berdasarkan uraian di atas maka dihipotesiskan:

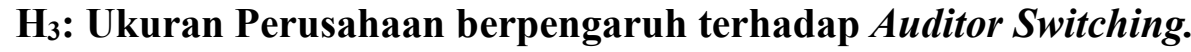

\section{Kepemilikan Manajerial Terhadap Auditor Switching}

Menurut Rianti (2014) kepemilikan manajerial adalah pemegang saham yang juga berarti sebagai pemilik di dalam perusahaan dari manajemen yang aktif dalam memberikan keputusan di perusahaan yang bersangkutan. Pengawasan yang tinggi menjadi hal yang perlu saat kepemilikan manajemen semakin meningkat. "Mekanisme pengawasan tersebut dapat dilakukan dengan memilih kualitas auditor yang lebih tinggi" (Maharani dan Purnomosidhi, 2012). Jadi, dapat disimpulkan bahwa semakin tinggi kepemilikan manajemen maka probabilitas perusahaan melakukan auditor switching semakin besar.

\section{$\mathrm{H}_{4}$ : Kepemilikan Manajerial berpengaruh terhadap Auditor Swithcing.}

\section{Pergantian Manajemen Terhadap Auditor Swithcing}

Penelitian yang dilakukan Rahman (2018) menyatakan dengan adanya manajemen yang baru mungkin juga diikuti oleh perubahan kebijakan dalam bidang akutansi, keuangan, dan pemilihan KAP. Biasanya suatu perusahaan akan mencari KAP yang sepadan dengan kebijakan dan pelaporan akuntansinya. Manajemen juga memerlukan auditor yang lebih berkualitas serta mampu memenuhi tuntutan pertumbuhan perusahaan yang cepat (Luthfiyati, 2016)

\section{H5: Pergantian manajemen berpengaruh terhadap Auditor Switching.}

\section{Financial Distress Terhadap Auditor Swithcing}

Perusahaan yang mengalami financial distress akan melakukan perbaikan dan menutupi atas kondisi tersebut. Salah satu cara yang dilakukan perusahaan adalah mencari auditor yang ingin bekerja sama untuk memanipulasi laporan keuangan agar terlihat lebih 
baik, dan dengan cara tersebut perusahaan akan mendapatkan dana dari kreditur dan investor. "Jika auditor sebelumnya tidak dapat memenuhi keinginan perusahaan untuk melakukan hal tersebut, perusahaan akan mencari Kantor Akuntan Publik yang baru dan dapat mengakomodasikan keinginannya" (Susanto, 2015). Hasil penelitian Wea dan Murdiawati (2015) dan Varadita (2012) menunjukkan bahwa bahwa financial distress berpengaruh signifikan terhadap auditor switching. Berdasarkan uraian di atas maka dihipotesiskan:

\section{H6: Financial Distress berpengaruh terhadap Auditor Switching.}

\section{Ukuran KAP Terhadap Auditor Swithcing}

Ukuran KAP merupakan ukuran yang digunakan untuk menentukan besar dan kecilnya suatu KAP (Fakhri, 2018). Para investor akan lebih cenderung pada data akuntansi yang dihasilkan oleh auditor yang bereputasi baik seperti KAP big four (Praptitorini dan Januarti, 2007). Akan tetapi tidak selamanya perusahaan akan mempertahankan KAP big four yang sama tersebut karena adanya kewajiban rotasi KAP.

\section{H7: Ukuran KAP berpengaruh terhadap Auditor Switching.}

\section{Opini Audit Terhadap Auditor Swithcing}

"Opini audit merupakan pernyataan atau pendapat yang diberikan oleh auditor, dan pernyataan atau pendapat diberikan agar perusahaan mengetahui tentang kewajaran laporan keuangannya" (Putra, 2014). Salah satu tujuan manajemen adalah menerima opini wajar tanpa pengecualian dari auditor untuk menarik investor. Perusahaan yang mendapatkan opini selain wajar tanpa pengecualian lebih cenderung mengganti auditornya dibandingkan perusahaan yang mendapatkan opini wajar tanpa pengecualian.

\section{$\mathrm{H}_{8}$ : Opini Audit berpengaruh terhadap Auditor Switching.}

\section{METODE PENELITIAN}

\section{Populasi dan Sampel}

Populasi dalam penelitian ini adalah seluruh perusahaan Finance yang terdaftar di Bursa Efek Indonesia (BEI) tahun periode 2013-2017. Metode pengambilan sampel yang digunakan dalam penelitian ini adalah metode purposive sampling. Populasi dalam penelitian ini berjumlah 85 perusahaan, dan perusahaan yang diambil untuk dijadikan sampel berdasarkan kriteria berjumlah 11 perusahaan, karena penelitian ini menggunakan data pada tahun 2013-2017 maka total sampel yang menjadi amatan dalam penelitian ini berjumlah 55 perusahaan Finance. 


\section{Jenis dan Sumber Data}

Jenis penelitian ini adalah penelitian kuantitatif dengan menggunakan data sekunder dari Bursa Efek Indonesia (BEI). Untuk memperoleh dan memilih perusahaan sampel terdapat beberapa sumber yang digunakan yaitu data nama-nama perusahaan yang terdaftar di Bursa Efek Indonesia didapatkan dari situs www.sahamok.ok dan data berupa laporan keuangan auditan dan annual report perusahaan sampel didapatkan dari situs resmi Bursa Efek Indonesia yaitu www.idx.co.id.

\section{Teknik Pengumpulan Data}

Teknik pengumpulan data yang digunakan adalah dokumentasi, yaitu dengan cara mengumpulkan, mencatat, mengolah, dan mengkaji data sekunder yang berupa laporan keuangan auditan, annual report perusahaan Finance yang terdaftar di Bursa Efek Indonesia (BEI) pada tahun 2013-2017.

\section{Definisi Operasional dan Pengukuran Variabel}

\section{Variabel Dependen: Auditor Switching}

Variabel dependen dalam penelitian ini adalah auditor switching atau pergantian auditor yang dilakukan perusahaan di luar peraturan wajib. Pengukuran variabel dependen tersebut menggunakan variabel dummy. Cara mengkuantifikasi variabel kualitatif di atas adalah Pemberian skor pada variabel ini adalah 1 (satu) pada perusahaan yang melakukan auditor switching dan 0 (nol) pada perusahaan yang tidak melakukan auditor switching.

\section{Variabel Independen: Pertumbuhan Perusahaan}

Pertumbuhan perusahaan diproksikan dengan tingkat penjualan pada suatu perusahaan. Semakin tinggi tingkat penjualan perusahaan maka akan semakin tinggi pula kemungkinan perusahaan untuk melakukan voluntary auditor switching. Rasio pertumbuhan perusahaan klien (M. Rizal, 2016) dapat dirumuskan sebagai berikut:

$$
\mathrm{dS}=\frac{\mathrm{St}-\mathrm{St}-\mathbf{1}}{\mathrm{St}-\mathbf{1}}
$$

Keterangan:

ds $\quad=$ Rasio pertumbuhan perusahaan klien.

St $\quad=$ Penjualan bersih pada tahun pergantian auditor.

St-1 = Penjualan bersih pada tahun sebelum pergantian auditor.

Variabel Independen: Audit Delay

Audit delay sebagai variabel independen, yaitu lamanya waktu penyelesaian audit yang diukur dari tanggal penutupan tahun buku hingga ditandatanganinya laporan auditan. 
Dilakukan pengukura secara kuantitatif (jumlah hari) dengan menghitung berapa jarak antara penutupan tahun buku hingga ditandatanganinya laporan auditan. Berdasarkan penelitian yang dilakukan oleh Sianturi (2014), audit delay dirumuskan sebagai berikut:

Audit Delay $=$ Tanggal Laporan Audit - Tanggal Laporan Keuangan

\section{Variabel Independen: Ukuran Perusahaan}

Ukuran perusahaan dapat diartikan sebagai besar kecilnya ukuran dari sebuah perusahaan yang dapat diukur dengan melihat jumlah aset dari sebuah perusahaan yang mengindikasikan bahwa suatu perusahaan tersebut berukuran kecil. "Variabel Ukuran Perusahaan diukur dengan menggunakan logaritma natural (Ln) atas total asset "(Nasser, et.al 2006).

\section{Variabel Independen: Kepemilikan Manajerial}

Kepemilikan manajemen merupakan persentase saham yang dimiliki oleh direksi, manajemen, maupun setiap pihak yang terlibat secara langsung dalam pembuatan keputusan perusahaan. Variabel kepemilikan manajemen dalam penelitian ini dengan menggunakan persentase saham yang dimiliki Dewan Direksi. Rumus menghitung kepemilikan manajerial:

$$
\mathrm{KM}=\frac{\mathrm{SM}}{\mathrm{SB}} \times 100 \%
$$

Keterangan:

$\mathrm{KM}=$ Kepemilikan Manajerial.

$\mathrm{SM} \quad=$ Total Saham yang dimiliki oleh Manajemen.

$\mathrm{SB} \quad=$ Jumlah Saham yang dikelola oleh perusahaan.

Variabel Independen: Pergantian Manajemen

Pergantian manajemen merupakan adanya pergantian direktur utama atau CEO (Chief Executive Officer) yang dilakukan oleh perusahaan dalam keputusan Rapat Umum Pemegang Saham. Pergantian manajemen diukur dengan menggunakan variabel dummy. Jika perusahaan telah mengganti direktur utama maka diberikan nilai $=1$ dan jika perusahaan tidak mengganti direktur utama maka diberi nilai $=0($ Aprillia 2013).

\section{Variabel Independen: Financial Distress}

Dalam penelitian ini, financial distresss dapat diukur dengan rasio DAR (Debt to Assets Ratio). Semakin tinggi proporsi DAR, maka akan semakin besar risiko keuangan bagi kreditur maupun pemegang saham. Tingkat rasio DAR yang aman adalah 50\%, Jika rasio DAR di atas 50\% merupakan salah satu indikator memburuknya kinerja keuangan sehingga perusahaan mengalami financial distress. Financial distress dapat dirumuskan sebagai berikut: 


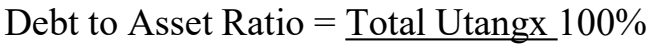

Total Asset

Keterangan:

DAR $=$ Debt to Assets Ratio

Variabel Independen: Ukuran KAP

Variabel Ukuran KAP dalam penelitian ini dibedakan menjadi dua kelompok, yaitu KAP yang berafiliasi dengan big four dan KAP yang tidak berafiliasi dengan big four. Variabel ukuran KAP menggunakan variabel dummy. Jika sebuah perusahaan diaudit oleh KAP big four maka diberikan nilai $=1$.Sedangkan jika sebuah perusahaan diaudit oleh KAP non-big four, maka diberikan nilai = 0" (Sinarwati, 2010).

Variabel Independen: Opini Audit

Opini audit merupakan pernyataan pendapat yang diberikan oleh auditor dalam menilai kewajaran laporan keuangan yang diauditnya. Variabel opini audit merupakan variabel dummy. Jika perusahaan klien menerima opini wajar tanpa pengecualian (unqualified opinion) dan wajar tanpa pengecualian dengan tambahan bahasa penjelas (unqualified opinion with explanatory paragraph) maka akan diberi nilai $=1$. Jika perusahaan klien menerima opini selain unqualified opinion dan unqualified opinion with explanatory paragraph maka akan diberi nilai $=0$ (Faradila, 2016).

\section{Metode Analisis Data}

Dalam penelitian ini, alat analisis yang digunakan adalah analisis regresi logistik (logistic regression) untuk menguji apakah probabilitas terjadi pada variabel yang terikat dapat diprediksi dengan variabel bebasnya.

\section{Model Regresi yang Terbentuk}

Analisis yang digunakan dalam penelitian ini adalah analisis regresi logistic (logistic regression). Adapun model regresi dalam penelitian:

$S W I T C H=\beta 0+$ b1PP + b2 AUDLY + b3 UPER + b4 KM + b5 PEM + b6 DAR + b7 UKAP + b8 OA + e

\section{HASIL PENELITIAN DAN PEMBAHASAN}

\section{Hasil Penelitian}

Hasil uji statistik deskriptif dapat dilihat pada Tabel 1 berikut: 


\section{Tabel 1}

\section{Hasil Uji Statistik Deskriptif}

\begin{tabular}{|c|c|c|c|c|c|}
\hline \multicolumn{6}{|c|}{ Descriptive Statistics } \\
\hline & $\mathbf{N}$ & Min & Max & Mean & Std. Deviation \\
\hline Auditor Switching & 55 & .00 & 1.00 & .2909 & .45837 \\
\hline Pertumbuhan Perusahaan & 55 & -1.00 & 2.58 & .1428 & .41588 \\
\hline Audit Delay & 55 & 16.00 & 149.00 & 64.1818 & 23.16374 \\
\hline Ukuran Perusahaan & 55 & 14.96 & 29.44 & 20.7840 & 4.82149 \\
\hline Kepemilikan Manajerial & 55 & .01 & 86.62 & 17.4113 & 25.08981 \\
\hline Pergantian Manajemen & 55 & .00 & 1.00 & .2727 & .44947 \\
\hline Financial distress & 55 & .00 & .89 & .5875 & .29865 \\
\hline Ukuran KAP & 55 & .00 & 1.00 & .5818 & .49781 \\
\hline Opini Audit & 55 & 1.00 & 1.00 & 1.0000 & .00000 \\
\hline Valid N (listwise) & 55 & & & & \\
\hline
\end{tabular}

Sumber: Olahan Data Sekunder, 2019

Berdasarkan hasil output statistik deskriptif pada tabel 1, maka dapat dikatakan bahwa:

1. Variabel auditor switching (AS) pada tabel 1 menunjukkan nilai min sebesar 0 dan max sebesar 1, mean sebesar 0,2909, dan standar deviasi 0,45837

2. Variabel pertumbuhan perusahaanpada tabel 1 menunjukkan nilai min sebesar -1,00 dan max sebesar 2,58, mean sebesar 0,1428, dan standar deviasi 0,41588.

3. Variabel audit delay pada tabel 1 menunjukkan nilai min sebesar 16 dan max sebesar 149, mean sebesar 64,1818, dan standar deviasi 23,16374.

4. Variabel Ukuran perusahaan pada tabel 1 menunjukkan nilai min sebesar 14,96 dan max sebesar 29,44, mean sebesar 20,7840, dan standar deviasi 4,82149.

5. Variabel kepemilikan manajerial pada tabel 1 menunjukkan nilai min sebesar 0,01 dan nilai max sebesar 86,62, mean sebesar 17,4113 dan standar deviasi sebesar 25,08981.

6. Variabel pergantian manjemen pada tabel 1 menunjukkan nilai min sebesar 0,00, max sebesar 1,00, mean 0,2727, dan standar deviasi 0,44947.

7. Variabel financial distress pada tabel 1 menunjukkan nilai min sebesar 0,0, max sebesar 0,89, mean 0,5875, dan standar deviasi 0,29865.

8. Variabel ukuran KAP pada tabel 1 menunjukkan nilai min sebesar 0,0, max sebesar 1,00, mean 0,5818 , dan standar deviasi 0,49781 .

9. Variabel Opini audit pada tabel 1 menunjukkan nilai min sebesar 1,0, max sebesar 1,0, mean 1,0000, dan standar deviasi 0,00000.

Hasil uji kesesuaian keseluruhan model dapat dilihat pada Tabel 2 berikut:

Tabel 2

Hasil Uji Kesesuaian Keseluruhan Model

\begin{tabular}{cc}
\hline Keterangan & -2 Log Likelihood \\
\hline -2LL Awal (Block Number $=0)$ & 66.326 \\
-2LL Akhir (Block Number $=1)$ & 29.031 \\
\hline
\end{tabular}

Sumber: Olahan Data Sekunder 2019 
Tabel 2 menunjukkan bahwa model 1 nilai -2LL Awal (Block Number $=0$ ) yaitu 66,326. Kemudian -2LL pada akhir (Block Number =1) 29,031. Penurunan nilai -2LL ini menunjukkan bahwa model regresi yang baik dengan kata lain model yang dihipotesiskan fit dengan data, artinya penambahan variabel bebas yaitu pertumbuhan perusahaan, audit delay, ukuran perusahaan,kepemilikan manajerial, pergantian manajemen, financial distress, ukuran KAP , dan Opini Audit akan memperbaiki model fit penelitian ini. Hasil uji Hosmer and Lemeshow dapat dilihat pada Tabel 3 berikut:

Tabel 3

Hasil Uji Hosmer and Lemeshow Test

\begin{tabular}{cccc}
\hline Step & Chi-square & df & Sig. \\
\hline 1 & 3.152 & 7 & .871 \\
\hline
\end{tabular}

Sumber: Olahan Data Sekunder, 2019

Kelayakan model regresi dinilai dengan mengggunakan Hosmer and Lemeshow's Goodness of Fit Test. Pengujian menunjukkan nilai Chi Square 3,152 dengan signifikan 0,871, karena nilai signifikan lebih besar dari 0,05 maka dapat disimpulkan bahwa model dapat diterima karena cocok dengan data observasinya. Hasil uji Koefisien Determinasi dapat dilihat pada Tabel 4 berikut:

\section{Tabel 4}

Hasil Uji Koefisien Determinasi (Nagelkerke's R Square)

\begin{tabular}{cccc}
\hline Step & $\mathbf{- 2 ~ L o g ~ l i k e l i h o o d ~}$ & Cox \& Snell R Square & Nagelkerke R Square \\
\hline 1 & $29.031^{\mathrm{a}}$ & .492 & .703 \\
\hline Sumber: Olahan Data Sekunder 2019 & &
\end{tabular}

Berdasarkan tabel 4 menunjukkan bahwa nilai Nagelkerke $R$ Square 0,703 yang berarti variabel dependen yang dapat dijelaskan oleh variabel independen adalah sebesar $70,3 \%$, sedangkan 30,7\% dijelaskan oleh variabel-variabel lain diluar model penelitian. Hasil uji multikolinearitas dapat dilihat pada Tabel 5 berikut:

\section{Tabel 5}

\section{Hasil Uji Multikolinearitas}

\begin{tabular}{llcccccccc}
\hline & Constant & X1 & X2 & X3 & X4 & X5 & X6 & X7 \\
\hline \multicolumn{1}{c}{ Constant } & 1.000 & -.677 & .183 & -.901 & .137 & -.541 & -.706 & -.330 \\
& Perumbuhan & -.677 & 1.000 & -.285 & .652 & -.205 & .213 & .601 & -.036 \\
& Perusahaan(X1) & .183 & -.285 & 1.000 & -.531 & .434 & -.407 & -.264 & .258 \\
& Audit Delay (X2) & -.901 & .652 & -.531 & 1.000 & -.377 & .617 & .572 & .155 \\
\multirow{5}{*}{$\mathbf{S t e p}$} & Ukuran Perusahaan & (X3) & & & & & & & \\
$\mathbf{1}$ & Kepemilikan Manajerial & .137 & -.205 & .434 & -.377 & 1.000 & -.192 & -.025 & .142 \\
& (X4) & & & & & & & & \\
& Pergantian manajemen & -.541 & .213 & -.407 & .617 & -.192 & 1.000 & .285 & -.042 \\
& (X5) & -.706 & .601 & -.264 & .572 & -.025 & .285 & 1.000 & .021 \\
& Financial distress (X6) & -.330 & -.036 & .258 & .155 & .142 & -.042 & .021 & 1.000 \\
\hline & Ukuran KAP (X7) & & & & & & & &
\end{tabular}

Sumber: Olahan Data Sekunder 2019 
Berdasarkan Tabel 5 menunjukkan bahwa tidak ada indikasi terjadinya multikolinearitas antar variabel independennya. Hal ini dapat dilihat dari korelasi antar variabel independen, dimana nilainya tidak ada yang melebihi 0,9 .

Hasil uji matriks klasifikasi dapat dilihat pada Tabel 6 berikut:

\section{Tabel 6}

\section{Hasil Uji Matriks Klasifikasi}

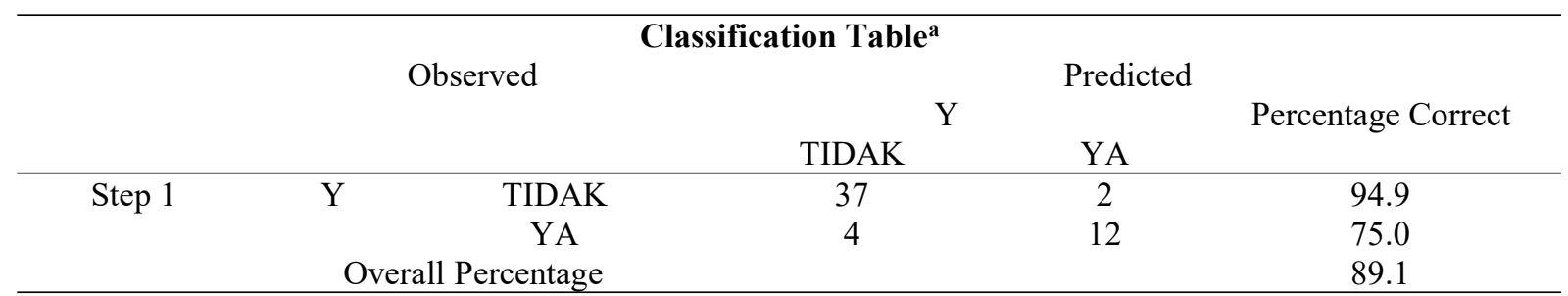

\section{Sumber: Olahan Data Sekunder, 2019}

Pada Tabel 6 menunjukkan bahwa kekuatan model regresi dalam memprediksi keputusan perusahaan melakukan auditor switching adalah sebesar 75\% dari total 11 perusahaan yang akan diprediksi melakukan auditor switching. Sedangkan kekuatan prediksi model untuk sampel yang tidak melakukan auditor switching adalah 94,9\% perusahaan yang diprediksi melakukan auditor switching, yang berarti bahwa dengan model regresi yang digunakan terdapat hanya beberapa perusahaan yang melakukan auditor switching. Sehingga secara keseluruhan ketepatan klasifikasi 89,1\%.

Hasil uji regresi logistik dapat dilihat pada Tabel 7 berikut:

\section{Tabel 7}

\section{Hasil Uji Regresi Logistik}

\begin{tabular}{clcccccc}
\hline & & \multicolumn{3}{c}{ Variables in the Equation } & & \multicolumn{2}{c}{} \\
& & B & S.E. & Wald & D & Sig. & Exp(B) \\
\hline Step & Auditor Switching & 7.099 & 3.015 & 5.546 & 1 & .019 & 1210.966 \\
$1^{\mathrm{a}}$ & Pertumbuhan Perusahaan & -.064 & .032 & 3.987 & 1 & .046 & .938 \\
& Audit Delay & .658 & .230 & 8.158 & 1 & .004 & 1.931 \\
& Ukuran Perusahaan & -2.871 & 2.800 & 1.052 & 1 & .305 & .057 \\
& Kepemilikan Manajerial & 3.365 & 1.369 & 6.044 & 1 & .014 & 28.936 \\
& Pergantian Manajemen & 4.528 & 2.249 & 4.052 & 1 & .044 & 92.570 \\
& Financial distress & -.566 & 1.127 & .252 & 1 & .616 & .568 \\
\multicolumn{1}{c}{ Constant } & -15.157 & 5.806 & 6.816 & 1 & .009 & .000 \\
\hline
\end{tabular}

Sumber: Olahan Data Sekunder, 2019

\section{Pembahasan}

\section{Pengaruh Pertumbuhan Perusahaan Terhadap Auditor Switching}

Tabel 7 menunjukkan nilai koefisien regresi positif sebesar 7,099 dengan tingkat signifikansi sebesar 0,019. Tingkat signifikansi tersebut lebih kecil dari $\alpha=5 \%(0,05)$ yang berarti bahwa $\mathrm{H}_{1}$ diterima sehingga dapat dikatakan bahwa perumbuhan perusahaan 
berpengaruh secara signifikan terhadap auditor switching. Seiring dengan pertumbuhan perusahaan, maka akan semakin kompleks kegiatan operasi perusahaan dan cenderung membutuhkan auditor yang lebih berkualitas sehingga pertumbuhan perusahaan juga diindikasikan sebagai salah satu unsur terjadinya auditor switching. Hasil penelitian ini sejalan dengan penelitian Wandari (2017) menyatakan bahwa pertumbuhan perusahaan memiliki pengaruh terhadap auditor switching.

\section{Pengaruh Audit Delay Terhadap Auditor Switching}

Tabel 7 menunjukkan nilai nilai koefisien regresi negatif sebesar 0,421 dengan tingkat signifikansi sebesar 0,046 . Tingkat signifikansi tersebut lebih kecil dari $\alpha=5 \%(0,05)$ yang berarti bahwa $\mathrm{H}_{2}$ diterima sehingga dapat dikatakan bahwa audit delay berpengaruh secara signifikan terhadap auditor switching. Hal ini berarti apabila terjadi keterlambatan publikasi laporan keuangan oleh perusahaan, akan menimbulkan pandangan negatif dari para investor dan berdampak pada harga saham serta keputusan publik. Selaras dengan pernyataan Soraya (2017) dan Robbitasari (2013) bahwa waktu penyelesaian tugas audit yang lama mengakibatkan keterlambatan dalam mempublikasikan laporan keuangan ke pasar modal sehungga akan menurunkan citra auditor dan mengakibatkan perusahaan dapat mengganti auditor.

\section{Pengaruh Ukuran Perusahaan Terhadap Auditor Switching}

Tabel 7 menunjukkan nilai koefisien regresi positif sebesar 0,658 dengan tingkat signifikansi sebesar 0,004 . Tingkat signifikansi tersebut lebih kecil dari $\alpha=5 \%(0,05)$ yang berarti bahwa $\mathrm{H}_{3}$ diterima sehingga dapat dikatakan bahwa ukuran perusahaan berpengaruh secara signifikan terhadap auditor switching. Hal ini menunjukkan bahwa semakin besar total aset sebuah perusahaan mengindikasikan bahwa ukuran perusahaan tersebut besar sehingga akan menyebabkan meningkatnya kesulitan bagi pemilik dalam memantau tindakan manajer sebagai prinsipal dan agen menjadi lebih jauh, sehingga perusahaan mungkin akan membutuhkan auditor yang baru (kualitas yang lebih tinggi) untuk menyediakan pemantauan yang lebih baik. Perusahaan besar juga cenderung menjaga citra perusahaannya dengan cara memilih kantor akuntan publik besar untuk mengaudit laporan keuangannya.

Konsisten dengan Nazrie et al. (2012) bahwa perusahaan besar akan mengalami kesulitan dalam mengawasi tindakan manajer sehingga perusahaan membutuhkan auditor baru yang lebih berkualitas. Konsisten dengan penelitian Netti (2014) bahwa ukuran perusahaan berpengaruh terhadap auditor switching. 


\section{Pengaruh Kepemilikan Manajerial Terhadap Auditor Switching}

Tabel 7 menunjukkan nilai koefisien regresi negatif sebesar 2,871 dengan tingkat signifikansi sebesar 0,305 . Tingkat signifikansi tersebut lebih besar dari $\alpha=5 \%(0,05)$ yang berarti bahwa $\mathrm{H}_{4}$ ditolak sehingga dapat dikatakan bahwa kepemilikan manajerial tidak berpengaruh secara signifikan terhadap auditor switching. Hal ini menunjukkan bahwa tingginya kepemilikan manajerial tidak akan mempengaruhi perusahaan untuk melakukan auditor switching, karena walaupun pada suatu perusahaan terdapat kepemilikan manajerial, belum tentu faktor tersebut yang mengakibatkan perusahaan melakukan auditor switching.

\section{Pengaruh Pergantian Manajemen Terhadap Auditor Switching}

Tabel 7 menunjukkan nilai koefisien regresi positif sebesar 3,365 dengan tingkat signifikansi sebesar 0,014. Tingkat signifikansi tersebut kecil dari $\alpha=5 \%(0,05)$ yang berarti bahwa $\mathrm{H}_{5}$ diterima sehingga dapat dikatakan bahwa pergantian manajemen berpengaruh secara signifikan terhadap auditor switching. Adanya manajemen yang baru mungkin juga diikuti oleh perubahan kebijakan dalam bidang akutansi, keuangan, dan pemilihan KAP yang sesuai dengan kebijakannya.

\section{Pengaruh Financial Distress Terhadap Auditor Switching}

Tabel 7 menunjukkan nilai nilai koefisien regresi negatif sebesar 4,528 dengan tingkat signifikansi sebesar 0,044 . Tingkat signifikansi tersebut kecil dari $\alpha=5 \%(0,05)$ yang berarti bahwa $\mathrm{H}_{6}$ diterima sehingga dapat dikatakan bahwa financial distress berpengaruh secara signifikan terhadap auditor switching. Hasil penelitian ini sejalan dengan penelitian Wea dan Murdiawati (2015) dan Varadita (2012) yang menunjukkan bahwa financial distress berpengaruh terhadap auditor switching. Perusahaan yang sedang mengalami financial distress cenderung melakukan auditor switching disebabkan karena perusahaan tidak dapat memenuhi biaya audit yang dibebankan oleh KAP yang mengauditnya, sehingga mencari KAP lain yang akan menawarkan fee audit yang lebih rendah dibandingkan KAP sebelumnya.

\section{Pengaruh Ukuran KAP Terhadap Auditor Switching}

Tabel 7 menunjukkan nilai koefisien regresi negatif sebesar 0,566 dengan tingkat signifikansi sebesar 0,616 . Tingkat signifikansi tersebut lebih besar dari $\alpha=5 \%(0,05)$ yang berarti bahwa $\mathrm{H}_{7}$ ditolak sehingga dapat dikatakan bahwa ukuran KAP tidak berpengaruh secara signifikan terhadap auditor switching. Ukuran KAP merupakan ukuran yang digunakan untuk menentukan besar dan kecilnya suatu KAP. Ukuran Kantor Akuntan Publik dapat dikatakan besar jika KAP tersebut berafiliasi dengan Big-4. Namun dalam hal ini 
mungkin disebabkan karena perusahaan menganggap tingkat reputasi KAP tidak ditentukan oleh klasifikasi big four atau non- big four, akan tetapi berdasarkan kualitas audit dan independensi auditor tersebut.

\section{Pengaruh Opini Audit Terhadap Auditor Switching}

Pengujian hipotesis $\mathrm{X}_{8}$ tidak menemukan hasil karena data didiskualifikasi otomatis oleh sistem SPSS artinya $\mathrm{H}_{8}$ ditolak. Hal ini dikarenakan data mengenai opini audit yang diproleh dari perusahaan finansial yang terdaftar di BEI menunjukan hasil yang seluruhnya sama, yaitu seluruh sampel perusahaan finansial yang terdaftar di BEI tahun 2013-2017 memiliki opini audit wajar tanpa pengecualian. Hasil penelitian ini menunjukan opini audit tidak berpengaruh terhadap auditor switching.

\section{SIMPULAN}

Dari hasil penelitian yang telah dilakukan maka dapa disimpulkan bahwa pertumbuhan perusahaan berpengaruh terhadap auditor switching. Audit delay berpengaruh terhadap auditor switching. Ukuran perusahaan berpengaruh terhadap auditor switching. Kepemilikan manajerial tidak berpengaruh terhadap auditor switching. Pergantian manajemen berpengaruh terhadap auditor switching. Financial distress berpengaruh terhadap auditor switching. Ukuran KAP tidak berpengaruh terhadap auditor switching, dan opini audit tidak berpengaruh terhadap auditor switching.

Berdasarkan hasil penelitian serta hal-hal yang terkait dengan keterbatasan penelitian ini, peneliti menyadari bahwa penelitian ini belum sempurna. Oleh sebab itu, peneliti menyarankan untuk penelitian selanjutanya menggunakan semua jenis perusahaan sehingga sampel yang digunakan dapat mewakili semua karakteristik dalam populasi. Selanjunya peneliti juga menyarankan untuk menambahkan variabel independen yang belum ada pada penelitian ini karena masih ada faktor-faktor lain yang mempengaruhi auditor switching

\section{REFERENSI}

Aminah, et al. (2017). Analisis Faktor-Faktor yang Mempengaruhi Auditor Switching Pada Perusahaan yang Tercatat di Bursa Efek Indonesia Tahun 2010-2015. Jurnal Akuntansi \& Keuangan .Vol 8, No. 1.

Aprianti, S., \& Hartaty, S. (2016). Pengaruh Ukuran KAP, Ukuran Perusahaan Klien, dan Tingkat Pertumbuhan Perusahaan Klien Terhadap Auditor Switching. Jurnal Akuntansi Politeknik Sekayu. Vol IV, No.1. 
Astyorini, C.D. (2015). Pengaruh Kepemilikan Manajemen, Pertumbuhan Perusahaan, Audit Delay, dan Reputasi KAP terhadap Pergantian Auditor Secara Voluntary. Skripsi. Yogyakarta: Universitas Sanata Dharma.

Fakhri, M. (2018). Pengaruh Opini Audit, Ukuran Kantor Akuntan Publik (KAP), dan Ukuran Perusahaan Terhadap Auditor Switching. E-Proceeding of Management. Vol.5, No.1

Luthfiyati, B. (2016). Pengaruh Ukuran Perusahaan, Opini Audit, Pergantian Manajemen, Ukuran KAP, dan Audit Tenure Terhadap Auditor Switching. Journal Of Accounting.

Kementerian Keuangan. (2003). Peraturan Menteri Keuangan No.359/KMK.06/2003 tentang Jasa Akuntan Publik. Jakarta.

Kementerian Keuangan. (2008). Peraturan Menteri Keuangan No. 17/PMK.01/2008 tentang Jasa Akuntan Publik. Jakarta.

Kementerian Keuangan. (2015). Peraturan Menteri Keuangan No. 20/2015 tentang Jasa Akuntan Publik. Jakarta.

Maharani, B. \& Purnomosidhi, B. (2012). Pergantian Auditor: Pengujian Teori yang Menghubungkan Biaya Agensi dengan Diferensiasi Kualitas Auditor (Studi Pada Perusahaan yang Terdaftar di Bursa Efek Indonesia). Jurnal Universitas Brawijaya.

Manto, J.I. \& Manda, D.L. (2018). Pengaruh Financial Distress, Pergantian Manajemen dan Ukuran KAP Terhadap Auditor Switching. Media Riset Akuntansi, Auditing \& Informasi.

Meidiyustiani, R. (2018). Implementation of Regression Logistic for Auditor Switching. International Journal of Pure and Applied Mathematics. Vol. 119, No. 15.

Nasser, T., Wahid, E.A., Nazri, S.N., \& Hudaib, M.. (2006). Auditor-Client Relationship: The Case of Audit Tenure and Auditor Switching in Malaysia. Managerial Auditing Journal. Vol. XXI, No. 7.

Netti, Y. (2015). Analisa Faktor-Faktor yang Mempengaruhi Auditor Switching Pada Perusahaan yang Terdaftar di Bursa Efek Indonesia. Skripsi. Semarang: UNDIP.

Oktaviana, Z., Suzan, L., Yudowati, S.P. (2017). The Influence of Auditor's Firm Size, Auditor Opinion, And Management Change to Auditor Switching. E-Proceeding of Management. Vol 4, No 2.

Otoritas Jasa Keuangan. (2016). Peraturan Otoritas Jasa Keuangan Nomor 29/POJK.04/2016 tentang Laporan Tahunan Emiten atau Perusahaan Publik.

Pasaribu, S.. (2017). Pengaruh Financial Distress, Opini Audit, Audit Delay dan Biaya Audit Terhadap Auditor Switching pada Perusahan Manufaktur Terbuka (Tbk) Yang Terdaftar di Bei Tahun 2013 - 2016. Skripsi. Medan: Universitas Sumatera Utara. 
Putra, I.W.D.W. (2014). Pengaruh Financial Distress, Rentabilitas, Pertumbuhan Perusahaan dan Opini Audit Pada Pergantian Auditor. EJurnal Akuntansi Universitas Udayana. pp. 308-323.

Rahman, M.A.T. (2018). Pengaruh Opini Audit, Financial Distress, Pertumbuhan Perusahaan Klien, Ukuran KAP dan Pergantian Manajemen Terhadap Auditor Switching. Skrispsi. Universitas Muhammadiyah Surakarta.

Robbitasari, A.P., \& Wiratmaja, I.D.N. (2013). Pengaruh Opini Audit, Going Concern, Kepemilikan Institusional, dan Audit Delay Pada Voluntary Auditor Switching. EJurnal Akuntansi Universitas Udayana. Vol. 5, No. 3.

Sianturi, R. (2014). Faktor yang Menentukan Audit Delay dan Pengaruhnya Terhadap Reaksi Investor (Studi Empiris Pada Perusahaan yang Terdaftar di Bursa Efek Indonesia Tahun 2010-2011). Skripsi. Bengkulu: Universitas Bengkulu.

Sinarwati, N. K. (2010). Mengapa Perusahaan Manufaktur yang Terdaftar di BEI Melakukan Pergantian Kantor Akuntan Publik?. Simposium Nasional Akuntansi XIII. Purwokerto, $1-20$.

Soraya, E. \& Haridhi, M. (2017). Faktor-Faktor yang Mempengaruhi Voluntary Auditor Switching (Studi Empiris pada Perusahaan Non Financing yang Terdaftar di Bursa Efek Indonesia Tahun 2011-2015). Jurnal Ilmiah Mahasiswa Ekonomi Akuntansi (JIMEKA). Vol. 2, No.1.

Susanto, O.P. (2015). Faktor-Faktor yang Mempengaruhi Perusahaan Melakukan Auditor Switching (Studi Empiris pada Perusahaan Manufaktur yang terdaftar di Bursa Efek Indonesia tahun 2010-2014). Skripsi. Surakarta: Universitas Muhammadiyah.

Varadita, F., \& Ardiyanto, M.D. (2012). Faktor-Faktor yang Mempengaruhi Pergantian Kantor Akuntan Publik di Perusahaan Go Publik yang Terdaftar di BEI. Disertasi. Fakultas Ekonomika dan Bisnis, Universitas Diponegoro.

Wea, A.N.S., \& Murdiawati, D. (2015). Faktor-Faktor yang Mempengaruhi Auditor Switching Secara Voluntary Pada Perusahaan Manufaktur. Jurnal Bisnis dan Ekonomi (JBE). Vol. 22, No. 2. 